\title{
Mitigation of faults in grid-connected wind-driven single machine brushless double-fed induction generator
}

\author{
Maged N. F. Nashed, Mona N. Eskander, Mahmoud A. Saleh \\ Electronics Research Institute, Cairo, Egypt
}

\begin{tabular}{l}
\hline \hline Article Info \\
\hline Article history: \\
Received Sep 1, 2018 \\
Revised Nov 22, 2018 \\
Accepted Jan 25, 2019 \\
\hline
\end{tabular}

\section{Keywords:}

Battery charge

DC link

Single machine brushless

doubly-fed induction generator

"SM-BDFIG"

Super-synchronous operation

\begin{abstract}
The effect of three-phase grid fault on the performance of a wind-driven single machine-brushless double fed induction generator (SM-BDFIG) is investigated. The fault-ride-through (FRT) of the grid-connected SM-BDFIG is then studied when installing a Static Synchronous Compensator (STATCOM) between the grid and the generator. Recovery from the grid fault before installing the STATCOM is studied and compared to the generation system recovery with installed STATCOM. The performances of the stator and rotor currents, stator and rotor voltages, electric torque, active power, reactive power, and battery pack voltage and current are presented for both cases. The total harmonic distortion (THD) of stator and rotor voltages and currents are also presented and compared. Results proved the faster recovery from grid faults, the continuity of currents and voltages, and the continuity of active power supplied to the grid when installing the STATCOM. However, slightly higher THD took place in the stator and rotor voltages and currents due to the switching pattern of the STATCOM.
\end{abstract}

Copyright $(2019$ Institute of Advanced Engineering and Science. All rights reserved.

\section{Corresponding Author:}

Maged N. F. Nashed,

Electronics Research Institute,

Cairo, Egypt.

Email:maged@eri.sci.eg

\section{INTRODUCTION}

Wind energy conversion system "WECS" are expected to supply11.7\%-12.6\% of global electricity by 2022. The main trend is to use doubly fed induction generator (DFIG) in recently manufactured WECS, due to the significant reduction in the rating of the associated converter, which was proved to be not more than $10 \%$ of the DFIG rating [1]. The benefits of DFIG are undeniable; however, the presence of copper slip rings and carbon brushes to transfer electrical energy to/from the rotating winding of the generator from/to the stationary electronic converter creates the need for frequent inspection and maintenance. The need for frequent maintenance due to the presence of brushes increases sharply the operating costs of WECS especially in remote areas and offshore installations [2,3].

In a previous paper by the authors, a new design for a brushless double fed induction generator BDFIM was proposed and published in [4]. Its dynamic response investigated in another paper [5]. It is the single machine brushless doubly fed induction generator (SM-BDFIG), which is composed of three main components; a regular three phase wound rotor induction machine, a power electronic converter, and a pack of rechargeable Lithium-ion batteries. The converter is mounted on the outer surface of a web reinforced hollow metallic (aluminum) or fiber glass cylinder. The battery packs are embedded in the inner part of the cylinder between the webs. The hollow cylinder is mechanically coupled with the induction machine on the same shaft. Therefore, all the three main components of the SM-BDFIG rotate with the same angular speed. The battery pack's two output terminals are electrically connected to de terminals of back to back converter. The ac terminals of the converter are connected to the rotor winding of the induction machine. Since all the three main components of the SM-BDFIG are mounted on the same shaft, i.e. all rotate with the same angular 
speed, then the connections between them are rigid electrical connections without any sliding contacts, slip rings, or brushes.

When the SM-BDFIG operates in the super-synchronous speed range, the excess slip power is transferred from the rotor of the induction machine to the converter. This power is converted to dc power which is used to charge the batteries.

One of the most important problems related to integration of wind generators to grid is the disconnection of the generators in the case of a decrease of network voltage under a certain value, i.e. voltage dip. A voltage dip is a short time (10 ms to 1 minute) event during which a reduction in r.m.s voltage magnitude occurs. It is often set only by two parameters, depth/magnitude and duration. The voltage dip magnitude is ranged from $10 \%$ to $90 \%$ of nominal voltage, with duration from half a cycle to $1 \mathrm{~min}$. With high wind energy penetration, disconnection of wind generators is not acceptable by grid operators. Many researchers dealt with grid faults ride through (FRT) in generation systems involving doubly fed induction generators using different techniques [6-7].

Others studied FRT techniques with various generators [8-10]. However, FRT in SM-BDFIG was not investigated. The behavior of this newly proposed machine during grid fault is expected to differ from the response of DFIG because its rotor is not connected to the grid, but to the battery pack as described above. Hence it is important to investigate the performance of the SM-BDFIG during grid faults and the mitigation of fault effect by integrating different devices.

In this paper mitigating the effect of ground faults on a grid-connected SM-BDFIG operating in the super-synchronous speed range is proposed by connecting a STATCOM between its stator terminals and the grid. Recovery from the grid fault before installing the STATCOM is studied and compared to the generation system recovery with installed STATCOM. The performances of the stator and rotor currents, stator and rotor voltages, electric torque, active power, reactive power, and battery pack voltage and current are presented for both cases. The THD of stator and rotor voltages and currents are also presented and compared. Results proved the faster recovery from grid faults, the continuity of currents and voltages, and the lower voltage and current transient peaks when installing the STATCOM. However, slightly higher THD took place in the stator and rotor voltages and currents due to the switching pattern of the STATCOM.

\section{BEHAVIOR OF SM-BDFIG DURING GRID FAULTS}

The SM-BDFIG, as explained before, is a brushless DFIG, without rotor connection to the grid. The wind turbines based on the DFIG are very sensitive to grid disturbances, especially to voltage dips. The abrupt drop of the grid voltage causes a dc component on the stator flux resulting in high rotor-induced voltages. However, the rotor converter voltage is rated to only a fraction of the rated rotor voltage. This gives rise to high rotor currents, and so, the power electronics converter should be disconnected from the rotor terminals. Conventionally, a resistive network called crowbar is connected to the rotor circuit, and the rotor side converter (RSC) is disabled. But the machine draws a high short circuit current when the crowbar is activated, as described in [11], resulting in a large amount of reactive power drawn from the power network, which is not acceptable when considering actual grid code requirements. Thus, other protection methods have to be investigated to ride-through grid faults safely and fulfill the grid codes. More recent grid codes impose that the turbine should be maintained connected during voltage dips and, in addition, should contribute to the voltage restoration injecting reactive current during the voltage dip.

There are other proposed solutions using additional hardware for fault ride-through of a DFIG using additional hardware such as, a series dynamic resistance in the rotor in or in the stator [12], or using a series line side converter (LSC) topology, or an external power electronic device. Dynamic voltage restorer (DVR) is used to compensate the faulty grid [13]. It is known that the DVR voltage is kept in quadrature with the line current to inject of reactive power to the grid to compensate for the voltage sag. However, the DVR voltage can be kept in quadrature with the line current only up to a certain value of voltage sag and beyond which the quadrature relationship cannot be maintained to correct the voltage sag. Since injecting reactive power is essential for quick voltage restoration at low voltages (large voltage sags), a STATCOM is an effective solution for voltage dips and ground faults for injecting reactive current into the grid to assist the grid voltage recovery [14]. STATCOM is expected to be the optimum solution for mitigation of faults in grid connected SM-BDFIG since its rotor is not connected to the grid, hence cannot afford reactive power to the grid without an external hardware device. Also it affords a path for active power generated by the wind turbine during the ground fault by utilizing this power to charge the battery of the STATCOM VSC instead of dissipating it in resistances. 


\section{MODELING THE GRID-CONNECTED WECS WITH SM-BDFIG}

The proposed system is a grid-connected SM-BDFIG operated by a horizontal axis wind turbine. A STATCOM is connected between the grid and the stator to mitigate the effects of grid faults. Figure 1 shows the proposed WECS with SM-BDFIG in Simulink software.

\subsection{SM-BDFIG Model}

Figure 2 shows the schematic of the SM_BDFIG. The voltage equations in the d-q synchronously rotating axes are given as, [15]:

$$
\begin{aligned}
& \mathrm{v}_{\mathrm{sd}}=\mathrm{R}_{\mathrm{s}} \mathrm{i}_{\mathrm{sd}}+\frac{\mathrm{d} \lambda_{\mathrm{sd}}}{\mathrm{dt}}-\omega_{\mathrm{s}} \lambda_{\mathrm{sq}} \\
& \mathrm{v}_{\mathrm{sq}}=\mathrm{R}_{\mathrm{s}} \mathrm{i}_{\mathrm{sq}}+\frac{\mathrm{d} \lambda_{\mathrm{sq}}}{\mathrm{dt}}+\omega_{\mathrm{s}} \lambda_{\mathrm{sd}} \\
& \mathrm{v}_{\mathrm{rd}}=\mathrm{R}_{\mathrm{r}} \mathrm{i}_{\mathrm{rd}}+\frac{\mathrm{d} \lambda_{\mathrm{rd}}}{\mathrm{dt}}-\omega_{\mathrm{r}} \lambda_{\mathrm{rq}} \\
& \mathrm{v}_{\mathrm{rq}}=\mathrm{R}_{\mathrm{r}} \mathrm{i}_{\mathrm{rq}}+\frac{\mathrm{d} \lambda_{\mathrm{rq}}}{\mathrm{dt}}+\omega_{\mathrm{r}} \lambda_{\mathrm{rd}}
\end{aligned}
$$

Where, the stator and rotor magnetic fluxes $\lambda$ are given by:



Figure 1. Block diagram proposed WECS with SM-BDFIG in Simulink software with STATCOM 


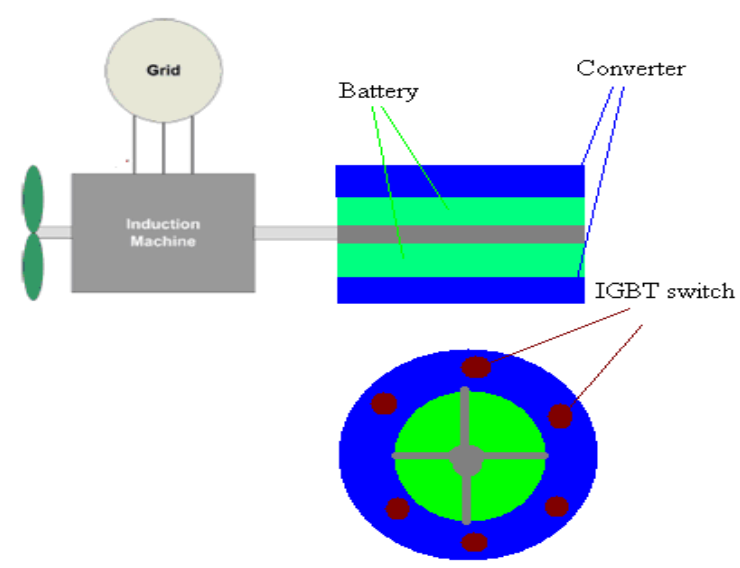

Figure 2. Schematic of SM-BDFIG

$$
\begin{aligned}
& \lambda_{\mathrm{sd}}=\left(\mathrm{L}_{\mathrm{ls}}+\mathrm{L}_{\mathrm{m}}\right) \mathrm{i}_{\mathrm{sd}}+\mathrm{L}_{\mathrm{m}} \mathrm{i}_{\mathrm{rd}} \\
& \lambda_{\mathrm{sq}}=\left(\mathrm{L}_{\mathrm{ls}}+\mathrm{L}_{\mathrm{m}}\right) \mathrm{i}_{\mathrm{sq}}+\mathrm{L}_{\mathrm{m}} \mathrm{i}_{\mathrm{rq}} \\
& \lambda_{\mathrm{rd}}=\left(\mathrm{L}_{\mathrm{lr}}+\mathrm{L}_{\mathrm{m}}\right) \mathrm{i}_{\mathrm{rd}}+\mathrm{L}_{\mathrm{m}} \mathrm{i}_{\mathrm{sd}} \\
& \lambda_{\mathrm{rq}}=\left(\mathrm{L}_{\mathrm{lr}}+\mathrm{L}_{\mathrm{m}}\right) \mathrm{i}_{\mathrm{rq}}+\mathrm{L}_{\mathrm{m}} \mathrm{i}_{\mathrm{sq}}
\end{aligned}
$$

Where:

$\mathrm{R}_{\mathrm{s}}, \mathrm{R}_{\mathrm{r}}, \mathrm{L}_{\mathrm{ls}}$, and $\mathrm{L}_{\mathrm{lr}}$ are resistances and leakage inductances for stator and rotor windings respectively; $\mathrm{L}_{\mathrm{m}}$ is the mutual inductance;

$\mathrm{v}_{\mathrm{sd}}, \mathrm{v}_{\mathrm{sq}}, \mathrm{v}_{\mathrm{rd}}, \mathrm{v}_{\mathrm{rq}}$, are the $\mathrm{d}$ and $\mathrm{q}$ components of the stator and rotor voltages respectively $i_{\mathrm{sd}}, \mathrm{i}_{\mathrm{sq}}, \mathrm{i}_{\mathrm{rd}}, \mathrm{i}_{\mathrm{rq}}$, are the $\mathrm{d}$ and $\mathrm{q}$ components of the stator and rotor currents respectively $\lambda_{\text {sd }}, \lambda_{\text {rq }}$, and $\lambda_{\text {rd }}, \lambda_{\text {rq }}$ are $\mathrm{d}$ and $\mathrm{q}$ components of stator and rotor magnetic flux respectively and $\omega_{\mathrm{s}}$ and $\omega_{\mathrm{r}}$ are angular frequencies of stator and rotor respectively

\subsection{Li-Ion Battery Model}

The charging equation for a Lithium-ion battery is modeled in Matlab software package as, [16]:

a) Discharge Model $\left(i^{*}>0\right)$

$$
f_{1}\left(i t, i^{*}, i\right)=E_{o}+K \frac{Q}{Q-i t} i^{*}-K \frac{Q}{Q-i t} i t+A e^{-B^{*} i t}
$$

b) Charge Model $\left(i^{*}<0\right)$

$$
f_{2}\left(i t, i^{*}, i\right)=E_{o}+K \frac{Q}{i t-0.1 Q} i^{*}-K \frac{Q}{Q-i t} i t+A e^{-B^{*} i t}
$$

Where:

$\mathrm{E}_{\mathrm{o}}=$ Constant voltage $(\mathrm{V})$

$\operatorname{Exp}(\mathrm{s})=$ Exponential zone dynamics $(\mathrm{V})$

$\operatorname{Sel}(s)$ represents the battery mode; $\operatorname{Sel}(s)=0$ during battery discharge, $\operatorname{Sel}(s)=1$ during battery charging. $\mathrm{K}=$ Polarization constant $(\mathrm{Ah})^{-1}$ or Polarization resistance $(\mathrm{Ohms})$

$\mathrm{i}^{*}=$ Low frequency current dynamics (A)

$\mathrm{i}=$ Battery current $(\mathrm{A})$

it $=$ Extracted capacity (Ah)

$\mathrm{Q}=$ Maximum battery capacity $(\mathrm{Ah})$

$\mathrm{A}=$ exponential voltage $(\mathrm{V})$

$\mathrm{B}=$ exponential capacity $(\mathrm{Ah})^{-1}$ 


\subsection{STATCOM}

The STATCOM, shown in Figure 3, is a shunt-connected reactive power compensation device that is capable of generating or absorbing reactive power. The STATCOM has three main components: voltage source converter (VSC), coupling transformer and the control circuit. The VSC is modeled as a six-pulse PWM-IGBT converter with a DC-link capacitor. If the system voltage is less than the voltage at the STATCOM terminals, the STATCOM acts as a capacitor and reactive power is injected from the STATCOM to the system. On the other hand, if the system voltage is higher than the voltage at the STATCOM terminal, the STATCOM behaves as an inductor and the reactive power transfers from the system to the STATCOM. Under normal operating conditions, both voltages are equal and there is no power exchange between the STATCOM and the AC system. The active and the reactive power exchange between the STATCOM and the AC system is controlled via the VSC firing angle $\alpha$ and the modulation index $\mathrm{m}$ to maintain the voltage at the point of connection and the DC-voltage within permissible limits, [17-20].

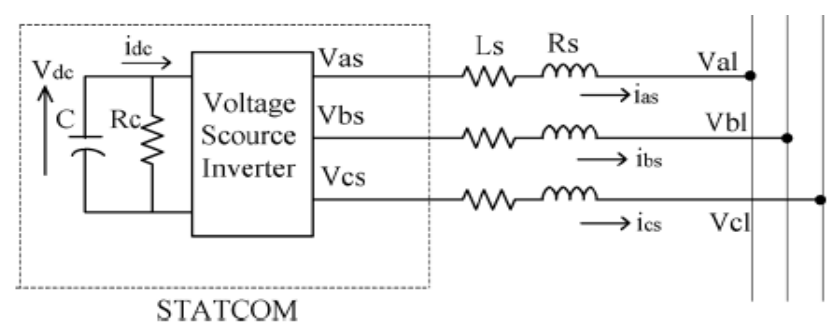

Figure 3. Basic STATCOM connected to a load bus in power system

\subsection{Control Strategy}

The control strategy must allow the wind turbine:

a) To remain connected to the power system and not consume active power during the fault.

b) To be provided with reactive power during the fault to assist voltage recovery.

c) To return to normal operation conditions after the fault.

d) The control scheme aims to supply the stator with constant voltage magnitude during grid faults.

It consists of a phase locked loop to track the magnitude and phase angle of the supply voltage during normal operation in order to detect the occurrence of faults. The PWM technique is used for switching the VSC with $2000 \mathrm{~Hz}$. The controller input is the error between to reference voltage and the grid voltage measured. The PI controller output adjusts the VSI switching angles to drive the error to zero, hence maintain the stator voltage during the grid fault to its reference value.

\section{SIMULATION RESULTS}

The performance of the SM-BDFIG during grid fault is investigated during super- synchronous speed operation without the STATCOM and when connecting the STATCOM. A speed of 1.04 of synchronous speed is assumed for simulation.

Figure 4 shows the grid voltage with a three phase ground fault from 0.3 to $0.4 \mathrm{sec}$. Figure $5 \mathrm{a}$ and $5 \mathrm{~b}$ show the single phase stator voltage during grid fault with and without the STATCOM respectively. It is clear that the STATCOM supplies stator voltage during the ground fault but with smaller magnitude. The stator voltage decreased from $122.6 \mathrm{~V}$ before fault to $116.8 \mathrm{~V}$ during the fault. i.e. $4.7 \%$ from original magnitude. The presence of stator voltage during the fault prevents the generator speed from increasing dramatically due to the continuous input mechanical power from the wind turbine. While without STATCOM, the stator voltage is nearly zero.

The THDs of stator voltage with and without STATCOM during normal operation, given in Figure $6 \mathrm{a}$ and $6 \mathrm{~b}$ respectively, reveal higher values with the installed device due to the switching of the VSI IGBTs. This increase is substituted by the safety of the SM-BDFIG during the ground faults. It is clear also that sub-harmonics exist in the stator voltage, as previously analyzed under steady state conditions by the authors of this paper in [15].

Figure 7 shows a slight increase in the THD of the stator voltage during grid fault than its value during normal operation (from $10.88 \%$ to $10.98 \%$ ) when installing the STATCOM. This proves the effect of the device in mitigating the consequences of ground fault with tolerable increase in voltage harmonics. 


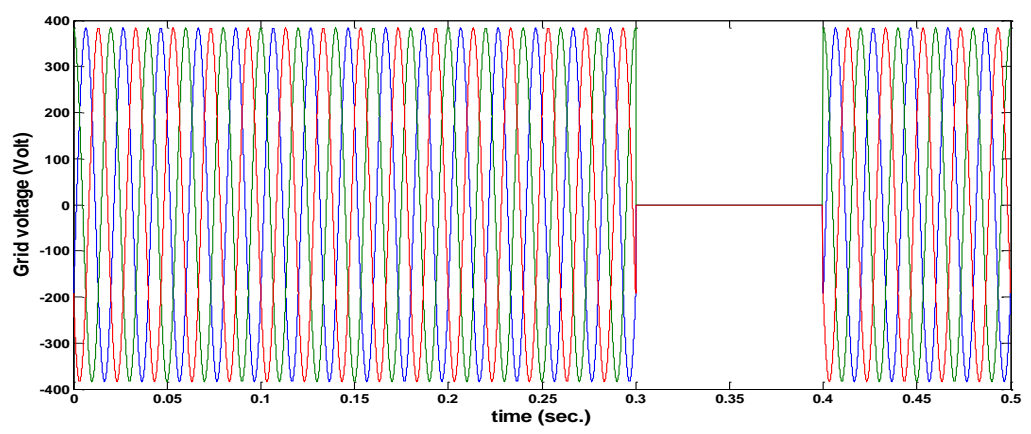

Figure 4. Grid voltage with the faults

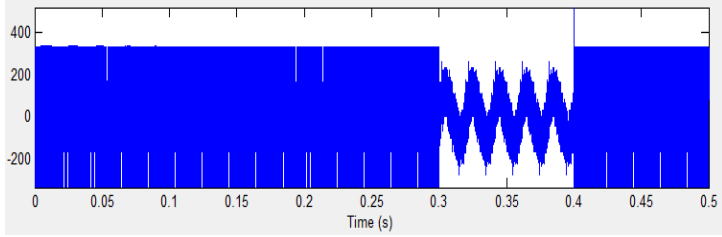

Figure 5(a). Stator voltage with STATCOM

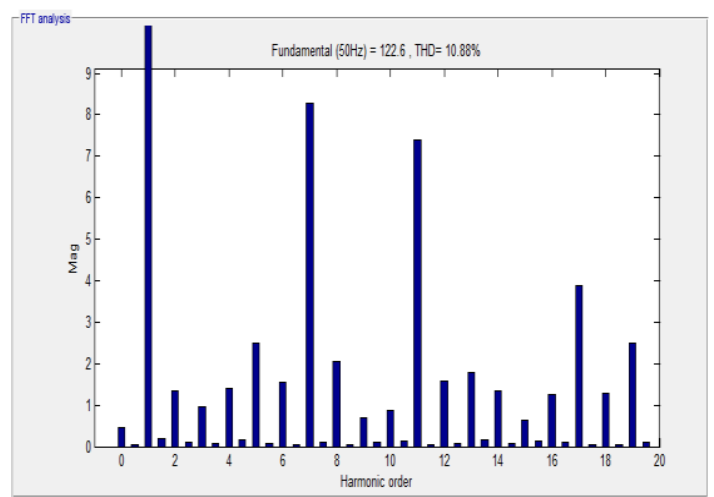

Figure 6(a). THD of stator voltage before fault with STATCOM

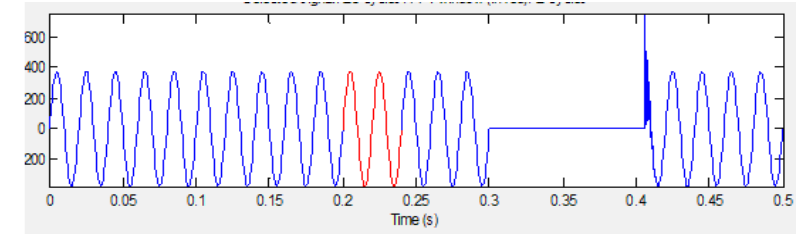

Figure 5(b). Stator voltage without STATCOM

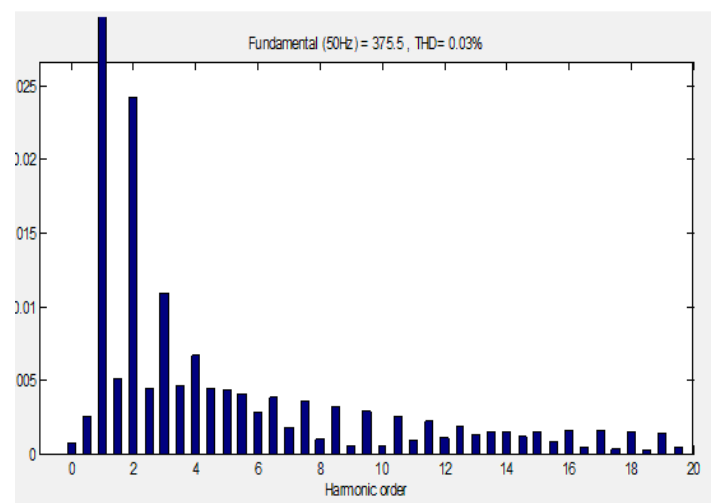

Figure 6(b). THD of stator voltage before fault without STATCOM

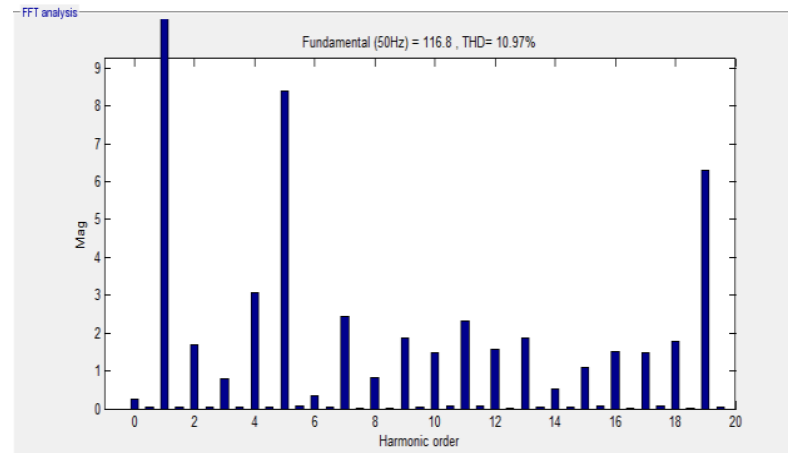

Figure 7. THD of stator voltage with STATCOM during grid fault

Figures $8 \mathrm{a}$ and $8 \mathrm{~b}$ show the single phase stator current during grid fault with and without the STATCOM respectively. It is clear that the STATCOM allows the continuity of the stator current during the 
ground fault but with smaller magnitude. The THDs of stator current with and without STATCOM, as given in Figure 9a and 9b, reveal higher values with the installed device due to the switching of the VSI IGBTs. This increase is substituted by the continuity of the stator current during the ground faults, avoiding the disconnection of the generator.

Figure 10 shows a slight increase in the THD of the stator current during grid fault than its value during normal operation (from $1.55 \%$ to $1.98 \%$ ) when installing the STATCOM. This proves the continuity of current flow with slight increase in harmonics.

Figures $11 \mathrm{a}$ and $\mathrm{b}$ show the single phase rotor voltage during grid fault with and without the STATCOM respectively. It is clear that the STATCOM leads to lower magnitude of the rotor voltage with lower transient peaks, hence protecting the rotor converter. Unlike the stator voltages, the THDs of rotor voltage with and without STATCOM, shown in Figure 12a and b, are nearly the same, demonstrating the decreased effect of the STATCOM switching pattern on the rotor circuit due to air gap.

Figure 13 shows a slight increase in the THD of the rotor voltage during grid fault than its value during normal operation (from $29.35 \%$ to $29.78 \%$ ) when installing the STATCOM. This proves the effect of the device in mitigating the consequences of ground fault on the rotor voltage with tolerable increase in voltage harmonics.

Figure 14a and 14b show the single phase rotor current during grid fault with and without the STATCOM. The decrease in the rotor current with installed STATCOM prevents damaging of the rotor converter. However a change from sinusoidal to a nearly trapezoidal current shape took place, leading to a higher THD, as given in Figure 15a and $15 \mathrm{~b}$ due to the shift from sinusoidal current profile.

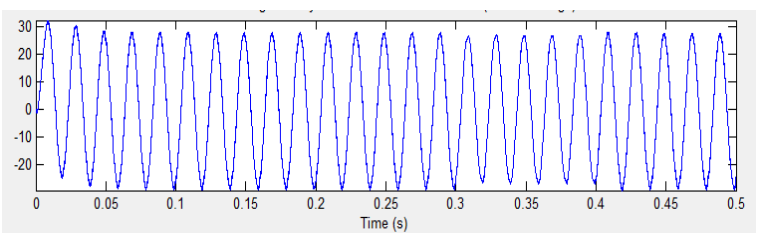

Figure 8(a). stator current with STATCOM

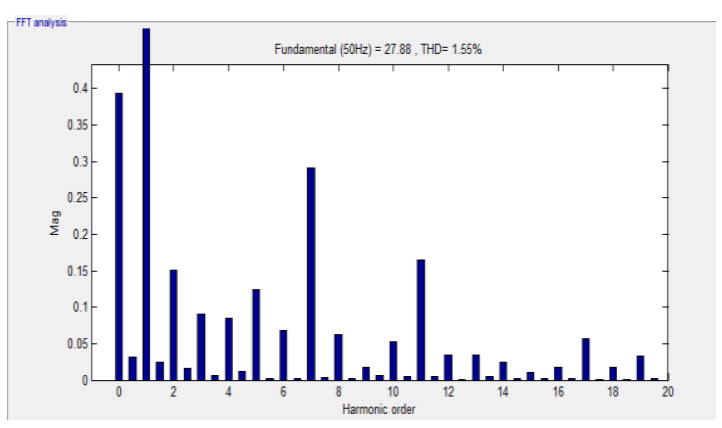

Figure 9(a). THDs of stator current before fault with STATCOM

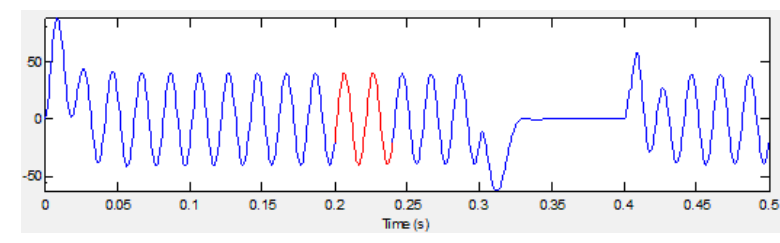

Figure 8(b). stator current without STATCOM

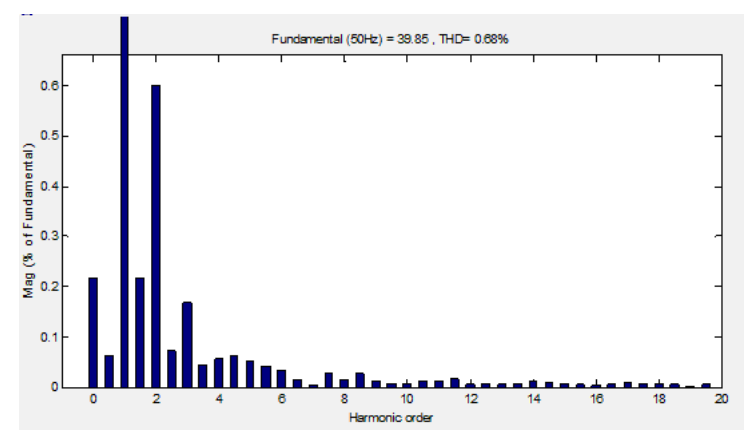

Figure 9(b). THDs of stator current before fault without STATCOM

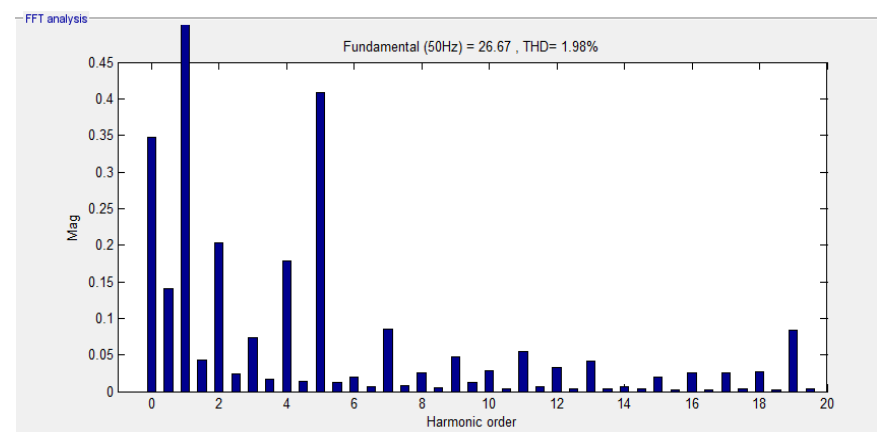

Figure 10. THD of stator current with STATCOM during grid fault 


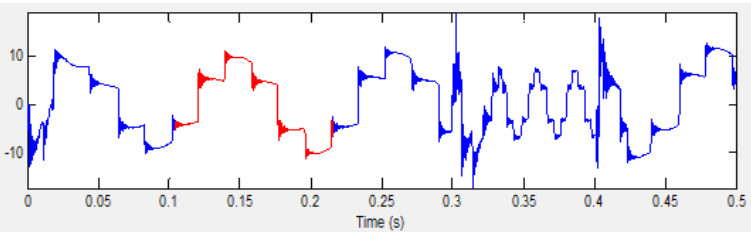

Figure 11(a). Rotor voltage with STATCOM

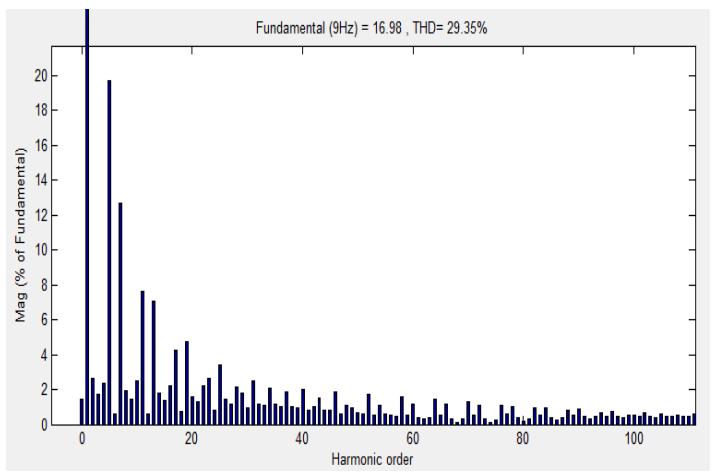

Figure 12(a). THD of rotor voltage before fault with STATCOM

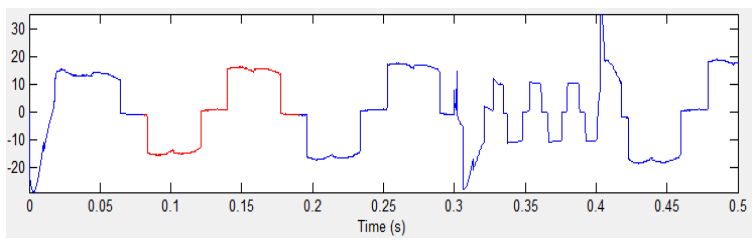

Figure 11(b). Rotor voltage without STATCOM

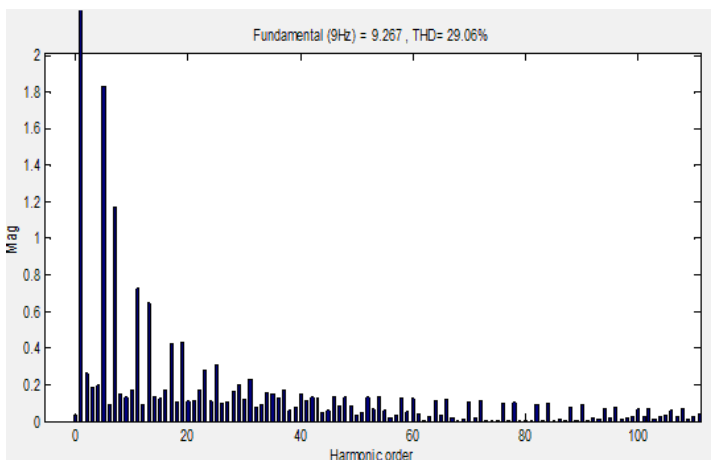

Figure 12(b). THD of rotor voltage before fault without STATCOM

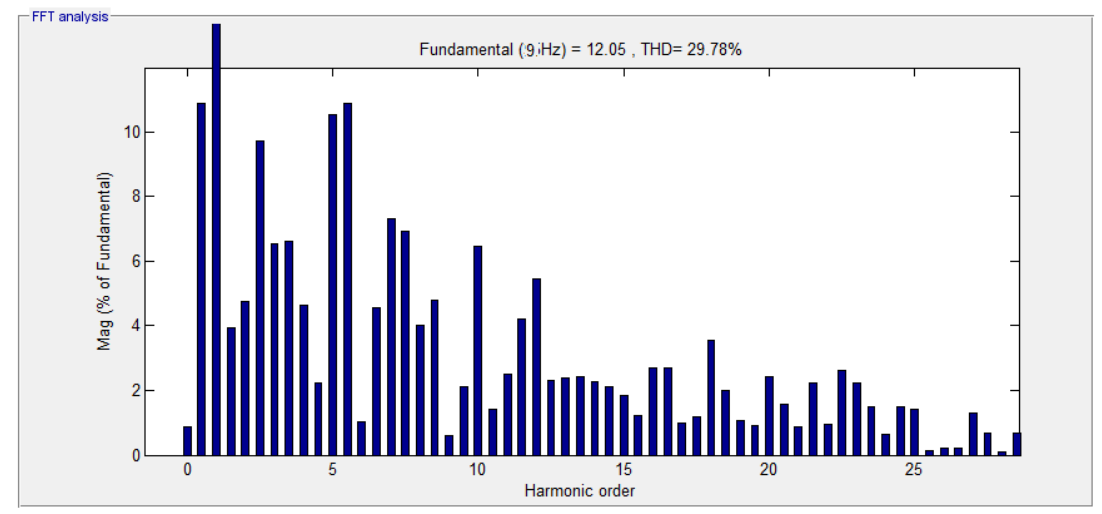

Figure 13. THD of rotor voltage with STATCOM during grid fault

Figure 16 shows an increase in the THD of the rotor current during grid fault than its value during normal operation (from $12.83 \%$ to $14.94 \%$ ) when installing the STATCOM. This increase is due to the effect of battery charging supplied by the rotor converter. However the increase in the current THD is compromised by the decrease in the rotor current magnitude, thus protecting the rotor converter from damage due to the ground fault.

Figures $17 \mathrm{a}$ and $17 \mathrm{~b}$ demonstrate the stator active and reactive power and the rotor active and reactive power with and without the STATCOM installation respectively. The continuous active power flow can be used to charge the battery supplying the VSC of the STATCOM during the grid fault. The reactive power generated by the installed device, enhances the grid voltage recovery.

The rotor over current, due to the ground fault, causes a sudden increase of the electric torque, typically reaching 2 to 3 times its rated value in the system without the STATCOM, as demonstrated in Figure (18b). While the electric torque during fault is within acceptable limits when installing the STATCOM as demonstrated in Figure 18a. However, manufacturers usually install a slip clutch in the shaft in order to prevent the torque peak from damaging the costly gearbox.

The battery voltage and current are shown in Figure (19), while installing the STATCOM. The grid fault resulted in considerable ripples in battery voltage and current during its occurrence. However, the charging process continued. 


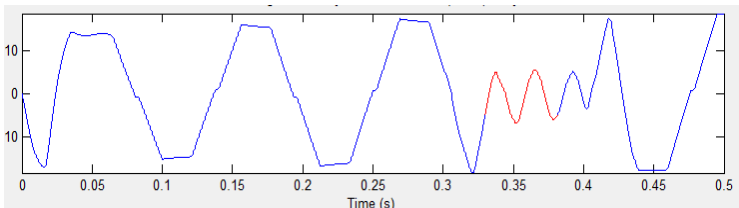

Figure 14(a). Rotor current with STATCOM

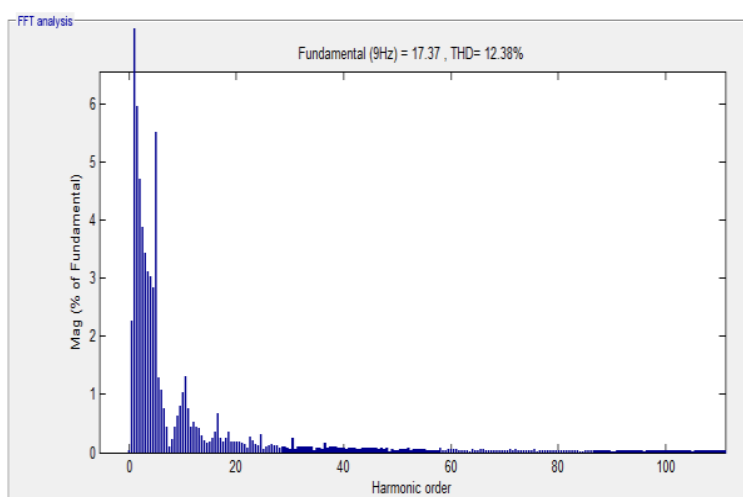

Figure 15(b). The THDs of rotor current before fault with STATCOM

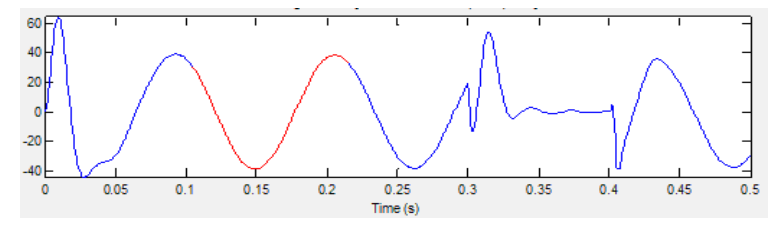

Figure 14(b). Rotor current without STATCOM

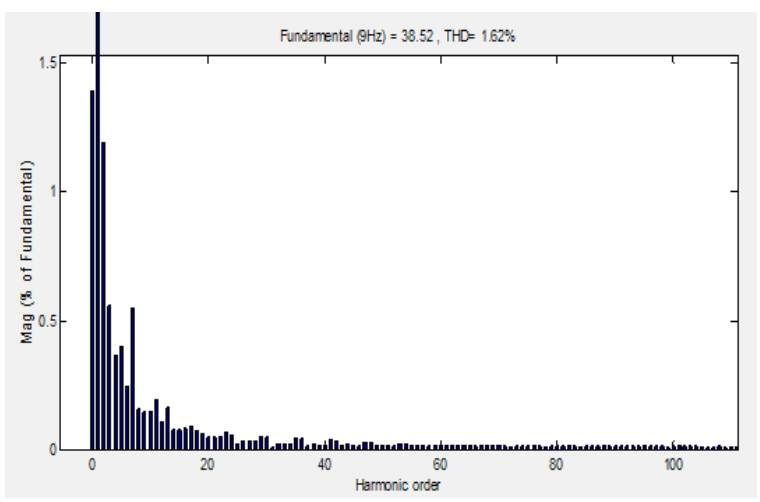

Figure 15(b). The THDs of rotor current before fault

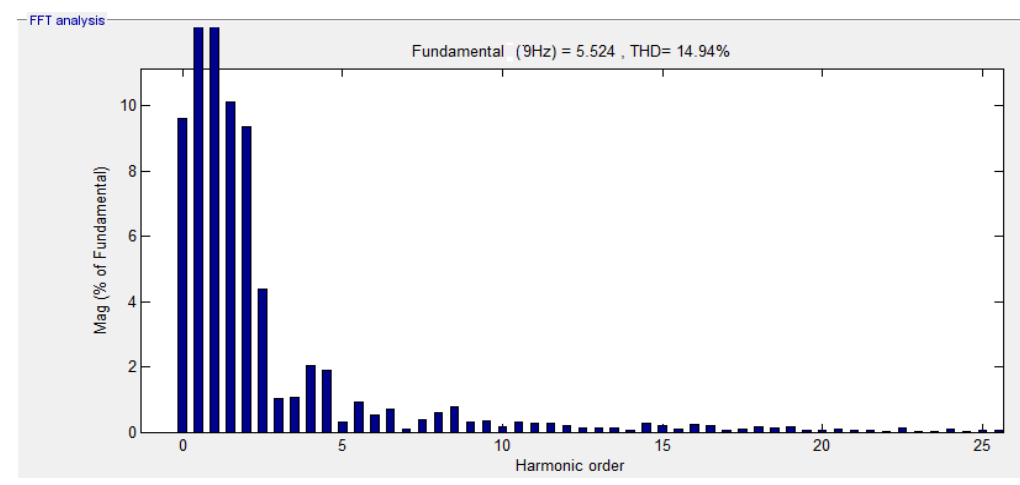

Figure 16. THDs of rotor current during grid fault
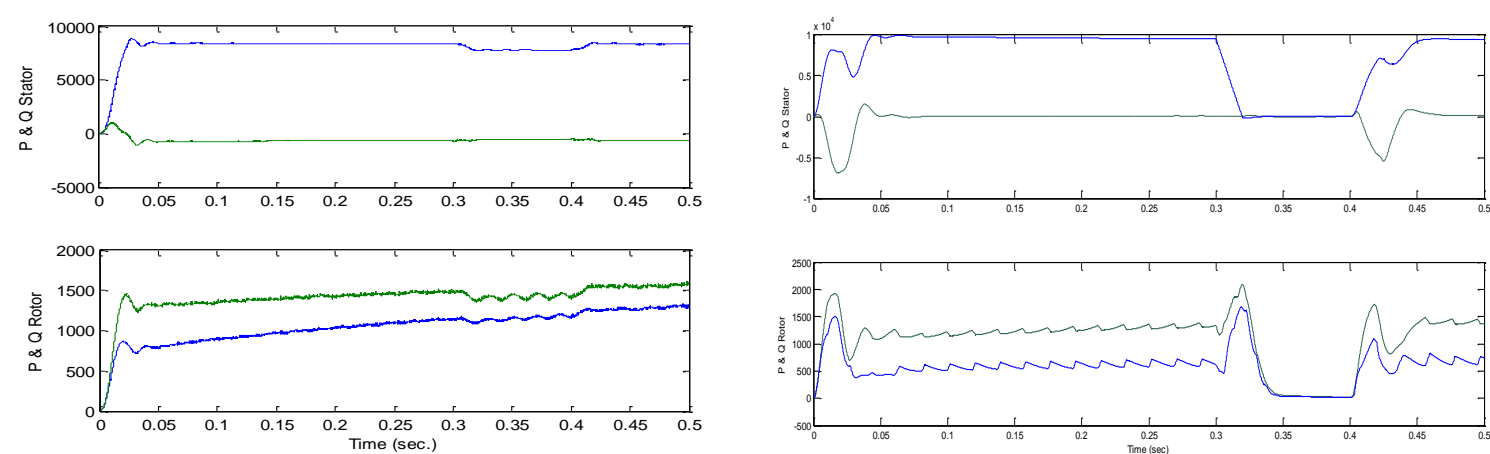

Figure 17(a). Active \& reactive power of stator \& rotor with STATCOM



Figure 17(b). Active \& reactive power of stator \& rotor without STATCOM 


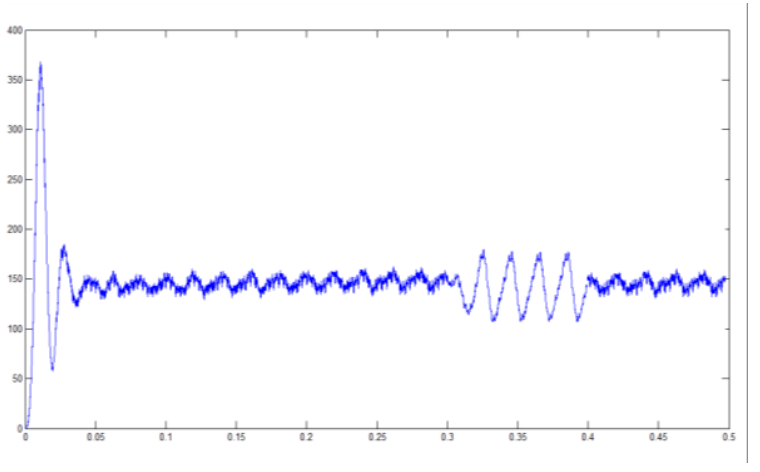

Figure 18(a). Electromagnetic Torque with STATCOM

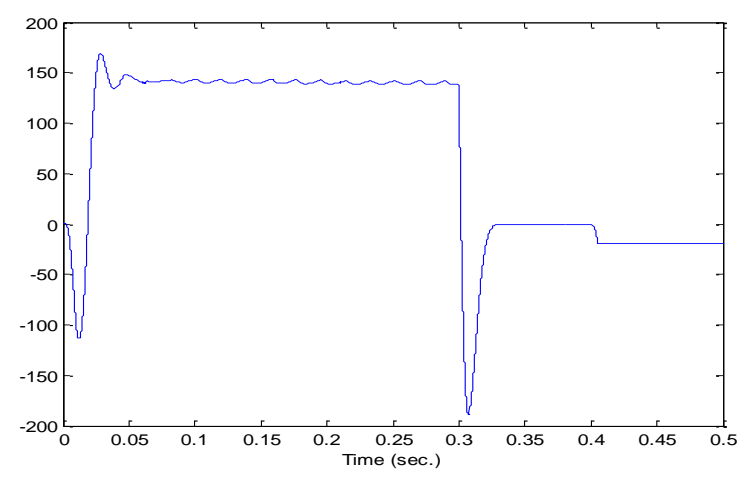

Figure 18(b). Electromagnetic Torque without STATCOM
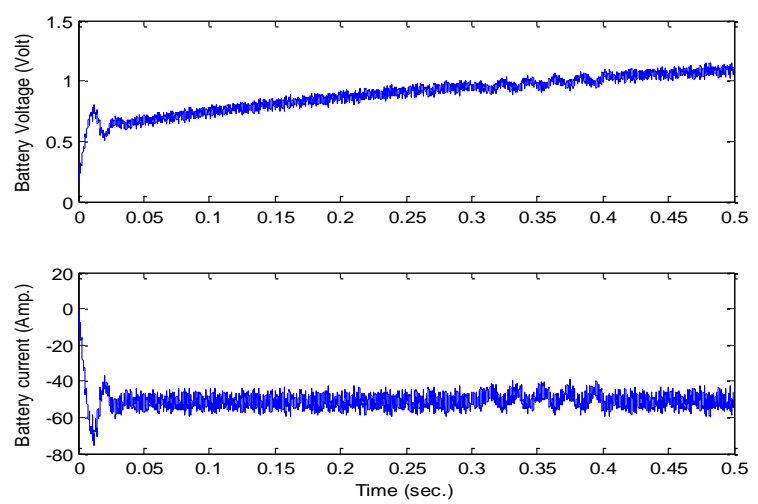

Figure 19. Battery voltage and current

\section{CONCLUSION}

The three phase fault mitigation of a grid connected new design of a single machine brushless double-fed induction generator is investigated using STATCOM. A comparison between the performance of the SM-BDFIG with and without the STATCOM is presented, showing the importance of the device in improving the system performance during faults. The SM-BDFIG is driven by a wind turbine at supersynchronous speed, supplying the grid with active power and charging a battery pack via a rectifier connected to the rotor circuit. The PI-controlled STATCOM decreased the effect of fault on the stator and rotor voltages and currents as well as on the battery charging performance. The grid fault caused a tolerable increase in the THD of currents and voltages, due to the switching of the VSC. The torque increase due to the grid fault is tolerable when installing the STATCOM and is much lower than its magnitude without the STATCOM. The battery charging was continuous during the grid fault with low ripples.

\section{Appendix}

Data of the Simulated Machine

Rated Power: 500 KVA,

Voltage : 690 Volt, $60 \mathrm{~Hz}$,

No. of Poles : 4,

Stator Resistance : $10.6 \mathrm{~m} \Omega$,

Stator Inductance : $.823 \mathrm{~m} \mathrm{H}$,

Rotor Resistance : $21.7 \mathrm{~m} \Omega$,

Rotor Inductance : .765 m H,

Mutual Inductance : $30.6 \mathrm{~m} \mathrm{H}$,

Data of Lithium-Ion Battery:

Nominal Voltage $=3.7 \mathrm{~V}$ 
Rated Capacity $=2.15 \mathrm{Ah}$

Fully Charged Voltage $=4.2 \mathrm{~V}$

Internal impedance $=150(\mathrm{~m} \Omega)$

No. of batteries in series $=5$

\section{REFERENCES}

[1] "Global Wind Report 2017" published by Global wind energy council http://gwec.net/publications/global-windreport-2/ February 2018.

[2] Cardenas R, Pena R, and Clare J. "Control of a wind generation system based on brushless doubly-fed induction generator fed by a matrix converter" Electric Power Systems Research. Vol. 103, 2013, pp: 49-60.

[3] Duro Basic, Jian Guo Zhu, and Gerard Boardmau, "Transient performance study of a brushless doubly fed twin stator induction generator" IEEE Trans. Energy Conversion, Vol. 18, No. 3, 2003; pp: 400-408.

[4] Mahmoud Abdel Halim Saleh, and Mona N Eskander, "Single Machine Brushless DFIG for Grid-Connected and Stand-Alone WECS", British Journal of Applied Science \& Technology Vol.4, issue 24, 2014, pp. 3550-3562.

[5] Mona N Eskander, Mahmoud Abdel Halim Saleh, and Maged N F. Nashed "Dynamic Performance of a Single Machine Brushless DFIG during Wind Speed Variation" International Journal of Engineering Research (IJER), Vol. 4, Issue No. 7, July 2015, pp: 378-383.

[6] Alejandro Rol'an, Felipe C'orcoles, and Joaqu'in Pedra, "Doubly Fed Induction Generator Subject to Symmetrical Voltage Sags", IEEE Transactions on Energy Conversion, Vol. 26, No. 4, December 2011, pp. 1219-1229.

[7] Ahmad Osman Ibrahim, and Thanh Hai Nguyen,"A Fault Ride-Through Technique of DFIG Wind Turbine Systems Using Dynamic Voltage Restorers", IEEE Transactions on Energy Conversion, Vol. 26, No. 3, December 2011, pp. 871-882.

[8] A. Hamzeh, Sadeq A. Hamed, and Zakaria Al-Omari, "Wind Generation Impact on Symmetrical Fault Level at Grid Buses" International Journal of Electrical and Computer Engineering (IJECE), Vol. 8, No. 5, October 2018, pp. 2682 2690

[9] Maaref, Hedi Dhouibi, Zineb Simeu-Abazi, and Hassani Mssaoud "Modeling and Fault Diagnosis Using Mixed Approach: Hybrid Dynamical Systems with Unknown Disturbances" IAES International Journal of Robotics and Automation (IJRA), Vol 7, No 1, March 2018

[10] Abdelhaq Amar bensaber, Mustapha Benghanem, Mohammed Amar bensaber, and Abdelmadjid. Guerouad "Nonlinear adaptive control for wind turbine under wind speed variation" IAES International Journal of Robotics and Automation (IJRA), Vol 7, No 2: June 2018

[11] Pannell G, Atkinson DJ, and Zahawi B., "Minimum-threshold crowbar for a fault-ride-through grid-code-compliant DFIG wind turbine", IEEE Ttrans. on Energy Conversion, Vol. 25, No. 3, Sept. 2010, pp: 750-759.

[12] P. K. Gayen, D. Chatterjee, and S. K. Goswami, "An improved low voltage ride-through performance of DFIG based wind plant using stator dynamic composite fault current limiter," ISA Trans., Vol. 62, No. 3, May 2016, pp. 333-348.

[13] P. Roncero-Sánchez, E. Acha, J. E. Ortega-Calderon Vicente Feliu, and A. García-Cerrada, "A versatile control scheme for a dynamic voltage restorer for power-quality improvement”, IEEE Trans., Power Del., Vol. 24, No. 1, Jan. 2009, pp. 277-284.

[14] S. T. Chavhan, C. Bhattar, P. V. Koli, and V. S. Rathod, "Application of STATCOM for power quality improvement of grid integrated wind mill," in Proc. IEEE 9th Int. Conf. Intell. Syst. Control (ISCO), Jan. 2015, pp. 1-7.

[15] Arantxa Tapia, Gerardo Tapia, J. Xabier Ostolaza, and José Ramón Sáenz, "Modeling and Control of a Wind Turbine Driven Doubly Fed Induction Generator", IEEE Trans. on Energy Conversion, Vol. 18, No. 2, June 2003, pp. : 194-205.

[16] Bimal K Bose, "Modern Power Electronics and AC Drives" Textbook published by 2002 Prentice-Hall,Inc, ISBN;0-13-016743-6

[17] Mahmoud Abdel Halim Saleh, Maged N F. Nashed, and Mona N Eskander, "Steady State Analysis of Wind Driven SM-BDFIG in the Super-Synchronous Range of operation" International Journal of Engineering Research (IJER), Vol 4, Issue 8, August 2015, pp. 412-418.

[18] Mona N Eskander, Mahmoud Abdel Halim Saleh, Maged N F. Nashed, and Sana I Amer, "Superiority of LVRT of Grid Connected Wind Energy Conversion System Using Unified Power Quality Controller" International Electrical Engineering Journal (IEEJ), Vol. 6, No. 6, June 2015, pp. 1925-1930.

[19] Mahmoud Abdel Halim Saleh, Mona N Eskander, and Sana I Amer, "Fault Ride Through in Grid-connected WECS Using FACTS" British Journal of Applied Science \& Technology, Vol. 4, No. 16, June 2014, pp: 2382-2394.

[20] Mahmoud A. Saleh, Mona N. Eskander, Maged N. F. Nashed, "Sub-Harmonics in Wind Driven SM-DFIG in the Super-Synchronous Range of Operation", International Journal of Engineering Research, Vol. 4, No.11, pp : 586-591. 